\title{
Indoor Particle Alpha Radioactivity Origins in Occupied Homes
}

\author{
Choong-Min Kang ${ }^{*}$, Man Liu ${ }^{1}$, Eric Garshick², Petros Koutrakis ${ }^{1}$ \\ ${ }^{1}$ Exposure, Epidemiology, and Risk Program, Department of Environmental Health, Harvard T.H. Chan School of Public \\ Health, Boston, MA 02215, USA \\ ${ }^{2}$ Pulmonary, Allergy, Sleep, and Critical Care Medicine Section, Medical Service, VA Boston Healthcare System; \\ Channing Division of Network Medicine, Brigham \& Women's Hospital; Harvard Medical School, Boston, MA 02130, \\ USA
}

\begin{abstract}
Exposure to radioactivity inside homes potentially poses severe health risks which can be exacerbated by the interaction between radioactive particles and fine indoor particles; in particular, the presence of $\alpha$ particles are a key risk factor. Hence, in this study, particle radioactivity was concurrently measured in the family rooms and basements of 26 homes to assess its concentrations and identify its sources, both indoors and outdoors, across two seasons. The levels of radon, air ions, and particle radioactivity, which included short- and long-lived $\alpha$-activity (SLA and LLA, respectively), varied greatly but were substantially higher in the basements. Also, particle radioactivity - as well as $\mathrm{PM}_{2.5}$ and sulfur concentrations - were lower during the heating season. SLA was associated with radon, which was consistently of indoor origin, whereas LLA was more strongly related to the sulfur measured in indoor $\mathrm{PM}_{2.5}$, which is a proxy of outdoor infiltration. A regression model adjusted for sulfur and SLA also indicated a predominance of outdoor sources, likely due to the short residence time of indoor particles. Our results suggest that radiation in homes originates from both the decay of indoor radon and the infiltration of outdoor radioactivity.
\end{abstract}

Keywords: Radioactivity origin; Radon; Particle radioactivity; Short-lived $\alpha$-activity; Long-lived $\alpha$-activity.

\section{INTRODUCTION}

Indoor air pollution is an important contributor to the global burden of disease (WHO, 2007). In the United States, people spend over $90 \%$ of their time indoors at home, school, office, and vehicles (U.S. EPA, 1997). Indoor air may contain a large spectrum of pollutants of indoor and outdoor origin including naturally occurring radon.

Radon is a noble gas with a half-life of 3.8 days that originates from rocks and soils and tends to concentrate in enclosed spaces such as underground mines or inside houses, particularly the basement. Radon is chemically inert and is rapidly inhaled and exhaled, whereas its progeny deposits onto lung airways. Two of its short-lived progeny $\left({ }^{218} \mathrm{Po}\right.$ and $\left.{ }^{214} \mathrm{Po}\right)$ and a long-lived progeny $\left({ }^{210} \mathrm{Po}\right)$ emit $\alpha$ radiation, which damages airway lining cells and increases cancer risk (U.S. EPA, 2003; WHO, 2009). Radon and its progeny are also the most important source of ionizing radiation in the indoor environment. Radon decays into charged metal ions.

\footnotetext{
* Corresponding author.

Tel.: 1617384 8754; Fax: 16173848859

E-mail address: cmkang@hsph.harvard.edu
}

These highly reactive ions eventually attach to other existing airborne particles that can be inhaled (Offermann et al., 1984; Kotrappa and Stieff, 2003). Freshly generated radon progeny initially $(<1 \mathrm{~s})$ exist as unattached ultrafine clusters with diameters ranging from 0.5 to $5 \mathrm{~nm}$. Within 1-100 s, these highly mobile and charged particle clusters attach to larger particles in the indoor air (Porstendorfer, 1994). When radioactive particles are inhaled, there is concern that the alpha radiation can interact with bronchial epithelial and other pulmonary cells, and potentially other tissues causing DNA damage (NRC, 1988). In many countries, indoor exposure to radioactivity is responsible for about half of all non-medical radiation exposure (UNSCEAR, 2000).

A number of survey studies have investigated residential levels of radon and its short-lived progeny (Hopke et al., 1995; Darby et al., 2005; WHO, 2009). These studies attributed indoor levels of radioactivity to the penetration of radon into the basement and did not take into account the indoor penetration of radioactive species from outdoor air. These radioactive species include long-lived radon progeny $\left({ }^{210} \mathrm{~Pb}\right.$, a half-life time of 22.3 years) that penetrates indoors, even though outdoor levels can be higher than indoor levels (Fisenne, 1993; Fisenne et al., 1996). For this reason, estimating the indoor and outdoor contribution to indoor exposure to particle radioactivity may help assess and 
contribute to the mitigation of health risks.

In this study, we report indoor measurements of radon and particle radioactivity including short- and long-lived $\alpha$ activity (SLA and LLA) from occupied homes in the metropolitan Boston area. Furthermore, we assess the indoor and outdoor origins of indoor alpha radioactivity.

\section{METHODS}

\section{Sampling Scheme}

We conducted indoor measurements in 26 houses of nonsmokers in the Boston metropolitan area between June 28, 2017, and December 15, 2018. Each home was sampled two times for 5 days over two seasons, a non-heating and heating season. For single-family homes, we did concurrent measurements in the family room and basement. For multifamily homes, we obtained measurements in the family room where residents spend the majority of their time. Two different sampling approaches were used: simple and intensive measurements. For the simple measurements, an indoor $\mathrm{PM}_{2.5}$ sampler, a dual radon charcoal canister, and a $\mathrm{CO}_{2}$ sensor (Model AZ0003; Global Sensors, Ormond Beach, FL) were placed in the family room of 10 multifamily homes. The $\mathrm{CO}_{2}$ sensor with a non-dispersive infrared diffusion sensor was placed next to the indoor $\mathrm{PM}_{2.5}$ samplers for real-time measurements of $\mathrm{CO}_{2}$, temperature, and relative humidity. For the intensive measurements, we also included measurements of SLA and air ion measurements (both described below) in the family room and basement of 16 single-family homes.

\section{Radon and Air Ions}

Radon levels were measured using passive canister samplers. The canister is 4 inches in diameter and 1 inch in thickness and contains activated carbon. In accordance with the United States Environmental Protection Agency (U.S. EPA)'s protocol, the canisters were placed at least 20 inches above the floor and 4 inches away from any indoor surface. After sample collection, the radon canisters were shipped on the same day to the Radon Testing Corporation of America (Springfield, MA) where radon levels were determined using a gamma spectrometer. The lower detection limit of this method is $3.7 \mathrm{~Bq} \mathrm{~m}^{-3}$. All analytical procedures were in complete accordance with current U.S. EPA protocols (EPA 402-R-92-004) for the analysis of radon in air. As per EPA recommendations for measurement reliability, duplicate radon samples were collected in most homes. Duplicate radon measurements were highly correlated with a slope of $0.88\left(\mathrm{R}^{2}=0.86, \mathrm{p}<0.001\right)$. Since relative humidity at the homes was not high (mean 48\%; data shown below), the effect of humidity on the measurement of radon would not expected to be significant. As another quality control, concurrent radon measurements using a charcoal sampler and an electret radon sampling unit (E-PERM; Rad Elec Inc., Frederick, MD) described in details below were highly correlated with a slope of $0.92\left(\mathrm{R}^{2}=0.85, \mathrm{p}<0.001\right)$, indicating a minor effect of humidity on the charcoal method. The charcoal method was used as a routine radon measurement for this study.

For air ions, we utilized ionometers to measure positive and negative ions from only 5 single-family homes due to instrumental malfunction. An ionometer (Model IM806v2; Holbach, Germany) was used to measure unattached radon progeny (e.g., ${ }^{218} \mathrm{Po},{ }^{214} \mathrm{~Pb},{ }^{214} \mathrm{Bi}$, and ${ }^{214} \mathrm{Po}$ ) expressed as the total number of positive and negative ions per cubic centimeter. The ionometer features two measurement channels for simultaneous measurement of positively and negatively charged air ions. The measuring system consists of two outer electrode tubes, each holding a central electrically insulated smaller electrode. Since the polarities of the applied voltage differ by electrode, one accelerates the positively charged ions and the other electrode the negatively charged ions to the inner electrode. Zero calibration was performed before the measurements. We performed simultaneous measurements using two ionometers which had agreement within $\pm 5 \%$ error and the average was reported.

\section{Particle a-activity from the Short-lived Progeny}

Short-lived $\alpha$-activity attached to particles was considered a surrogate of attached short-lived radon progeny. This $\alpha$-activity was measured using an electret-radon progeny integrating sampling unit (E-RPISU; Rad Elec Inc., Frederick, $\mathrm{MD})$. It collects radon progeny on a $25-\mathrm{mm}$ glass-fiber filter at a low-flow rate of $0.8 \mathrm{~L} \mathrm{~min}^{-1}$ and registers $\alpha$ radiation activity from the deposited progeny during the sample collection. This filter was mounted on the side of the electret ion chamber so that the collected progeny ionizes the air inside the chamber. The initially charged electret is neutralized by ions generated from radon progeny decay causing electret voltage to drop. This voltage drop is proportional to the time-integrated progeny concentration (Kotrappa and Stieff, 2003). The electret is a dielectric material carrying a permanent electrical charge and is used to monitor ions produced from $\alpha$ radiation emitted by radon progeny collected on a filter (Kotrappa et al., 1981; Goheen et al., 1994; Dua et al., 1999). After sample collection, the electret voltage drop was measured with a voltage reader, which was calibrated using references provided by the manufacturer. The lower detection limit of this determination was $3.9 \mathrm{~Bq} \mathrm{~m}^{-3}$, and the reproducibility was $5 \%$. In addition, the equilibrium factor (known as the $F$ factor) was also calculated from the ratio of radon and SLA. The F factor is defined as the ratio of the equilibrium equivalent concentration of radon to the actual $\alpha$ activity concentration of radon in air (Swedjemark, 1983), and accounts for the fraction of gas-phase radon converted to particle-phase short-lived progeny.

\section{Particle a-activity from the Long-lived Progeny}

Indoor $\mathrm{PM}_{2.5}$ samples were collected using a two-stage cascade impactor. The samplers collect particles in three size ranges at a flow rate of $5 \mathrm{~L} \mathrm{~min}^{-1}$. The two impactor stages are equipped with two slit-shaped acceleration nozzles and are followed by a backup Teflon filter at the third stage. The first two stages use polyurethane foam as impaction surfaces that collect particles above $10 \mu \mathrm{m}$ and between 2.5 and $10 \mu \mathrm{m}$ (Lee et al., 2006; Case et al., 2008). The third stage uses a $37-\mathrm{mm}$ Teflon filter supported by a drain disk and a stainless-steel screen to collect $\mathrm{PM}_{2.5}$. Teflon filters were weighed before and after sample collection using an electronic 
microbalance (Model MT-5; Mettler Toledo, Columbus, OH) at a controlled temperature and relative humidity to obtain gravimetric mass concentration. Subsequently, they were analyzed for sulfur and other elements using an energydispersive X-ray fluorescence (EDXRF) spectrometer (Model Epsilon 5; PANalytical, The Netherlands). The lower detection limit of sulfur determination was $1.5 \mathrm{ng} \mathrm{m}^{-3}$. A detailed description of the XRF analysis is also available elsewhere (Kang et al., 2014). Assuming that no significant sources of sulfur exist indoors, the indoor sulfur concentration can be used as a proxy of the infiltration of outdoor $\mathrm{PM}_{2.5}$ (Sarnat et al., 2002).

Particle $\alpha$-activity from long-lived radon progeny was measured on the $\mathrm{PM}_{2.5}$ filters. After storage for at least one year, $\alpha$ radiation was measured to evaluate particle radioactivity from long-lived progeny decay $\left({ }^{210} \mathrm{~Pb}\right.$ to $\left.{ }^{210} \mathrm{Po}\right)$ using a low-background proportional counter (Model LB4200; Canberra Industries, Inc., Meriden, CT) with a P10 carrier gas (10\% methane balanced with argon). We assessed various counting times and used 600 minutes to account for the low radioactivity level of the filter samples. The counter was calibrated with a $0.0518 \mu \mathrm{Ci}$ NIST traceable ${ }^{210}$ Po source on $5.7-\mathrm{cm}$ planchet and the counting $4 \pi$ efficiency was $40 \pm$ $1 \%$. The background level was below 0.1 counts $\min ^{-1}$ and the detection limit was $0.015 \mathrm{mBq} \mathrm{m}^{-3}$ with a counting time of 600 minutes and a sample volume of $36 \mathrm{~m}^{3}$. All $\alpha$-radiation activities except one sample measured from the filters were substantially higher than the detection limit. After one year of storage, the total $\alpha$ activity is dominated by ${ }^{210} \mathrm{Po}$ decay, which is the progeny of ${ }^{210} \mathrm{~Pb}$ that has the longest half-life (22.3 years). Therefore, LLA $(C)$ in the air at the time of sampling was estimated using the equation below (Sheets and Thompson, 1994):

$C=\frac{A_{\alpha(t) \cdot e^{\lambda t}}}{Q}$

where $A_{\alpha(t)}$ is $\alpha$-activity measurement ( $\left.\mathrm{mBq}\right) ; \lambda$ is the decay constant $\left(8.51 \times 10^{-5} \mathrm{~d}^{-1}\right)$ for ${ }^{210} \mathrm{~Pb} ; Q$ is air sample volume $\left(\mathrm{m}^{3}\right)$; and $t$ is the duration in days between sampling and measurement.

\section{Linear Mixed-effect Regression Analysis}

A linear mixed-effect regression model was used to estimate the association between the measurements associated with particle radioactivity. The model is useful to analyze data that include repeated measures, such as multiple data points for each home. A random intercept was used for each home, and a coefficient was analyzed as a fixed effect.

\section{RESULTS}

\section{Key Home Characteristics}

In total, 26 homes that included single-family and multifamily homes participated in this study. Table 1 presents the key characteristics of homes. The single-family homes included had a ground-floor living level, and the multifamily homes consisted of 5 multi-level apartments and 5
Table 1. Key home characteristics.

\begin{tabular}{ll}
\hline Characteristic & Number of homes \\
\hline House type: & \\
Single-family & 16 \\
Multi-family & 10 \\
Heating type: & \\
$\quad$ Forced air & 8 \\
Radiator & 18 \\
Heating fuel: & \\
LNG ${ }^{1}$ & 15 \\
Oil & 11 \\
Cooking fuel: & 10 \\
LNG & \\
Electricity & 16 \\
Central AC & \\
Yes & 12 \\
No & 14 \\
Ventilation: & \\
Exhaust/supply & 8 \\
Natural & 18 \\
\hline
\end{tabular}

${ }^{1}$ Liquid natural gas.

${ }^{2}$ Air conditioner.

condominiums. The year of construction ranged from 1900 to 2016 and the average living area was approximately $1,600 \mathrm{ft}^{2}$. As shown in Table 1, the key home characteristics are typical of homes in the northeastern US.

\section{Radon and Particle Radioactivity in Family Rooms and Basements}

Indoor measurements were conducted in the family room, or the family room and basement concurrently, and summarized in Tables 2 and 3. Radon levels averaged 54.9 \pm 59.7 (mean $\pm \mathrm{SD}) \mathrm{Bq} \mathrm{m}^{-3}$ ranging from 3.7 to $288.6 \mathrm{~Bq} \mathrm{~m}^{-3}$. The average radon levels in the family rooms and basements were $31.1 \pm 28.3$ and $105.0 \pm 76.6 \mathrm{~Bq} \mathrm{~m}^{-3}$, respectively. Radon levels were considerably higher in basements as compared to family rooms. Radon in buildings originates from soils adjacent to the foundation, construction materials such as concrete, and tap water when supplied from radiumbearing aquifers. Note also that radon levels varied greatly across homes. The U.S. EPA recommends that residential radon levels in the basements must be below $148 \mathrm{~Bq} \mathrm{~m}^{-3}$, an equivalent of $4 \mathrm{pCi} \mathrm{L}^{-1}$. If the radon levels are higher than the guideline, a mitigation system is suggested to reduce levels. Among our basement radon measurements, 5 out of 18 measurements exceeded this guideline.

Positive ions in family rooms averaged 1,064 \pm 636 ions $\mathrm{cm}^{-3}$ and negative ions averaged $981 \pm 843$ ions $\mathrm{cm}^{-3}$. In contrast, in basements, the corresponding positive ions averaged 2,876 $\pm 1,896$ ions $\mathrm{cm}^{-3}$ and the negative ions averaged $2,445 \pm 1,737$ ions $\mathrm{cm}^{-3}$. The difference by a factor of about two is likely due to the higher radon levels in the basement and/or the higher air exchange in family rooms. We also found somewhat diurnal variation in positive and negative ions (Fig. S1). Positive ions were highly correlated with negative ions $\left(\mathrm{R}^{2}=0.96, \mathrm{p}<0.001\right)$. Furthermore, radon levels were highly correlated with positive $\left(R^{2}=0.86\right.$, 
Table 2. Overall data summary.

\begin{tabular}{|c|c|c|c|c|c|}
\hline Species & Mean & SD & Min & Max & $\mathrm{N}$ \\
\hline $\operatorname{Radon}\left(\mathrm{Bq} \mathrm{m}^{-3}\right)$ & 54.9 & 59.7 & 3.7 & 288.6 & 56 \\
\hline Positive ions (ions $\mathrm{cm}^{-3}$ ) & 1,870 & 1,598 & 490 & 6,240 & 18 \\
\hline Negative ions (ions $\mathrm{cm}^{-3}$ ) & 1,632 & 1,476 & 132 & 5,403 & 18 \\
\hline $\mathrm{SLA}^{1}\left(\mathrm{~Bq} \mathrm{~m}^{-3}\right)$ & 47.4 & 36.5 & 5.3 & 164.4 & 26 \\
\hline $\operatorname{LLA}^{2}\left(\mathrm{mBq} \mathrm{m}^{-3}\right)$ & 1.11 & 0.61 & 0.09 & 3.50 & 54 \\
\hline $\mathrm{F}$ factor ${ }^{3}$ & 0.59 & 0.21 & 0.23 & 0.92 & 18 \\
\hline $\mathrm{PM}_{2.5}\left(\mu \mathrm{g} \mathrm{m}^{-3}\right)$ & 6.0 & 3.7 & 1.0 & 16.8 & 54 \\
\hline Sulfur $\left(\mu \mathrm{g} \mathrm{m}^{-3}\right)$ & 0.182 & 0.109 & 0.018 & 0.436 & 54 \\
\hline $\mathrm{CO}_{2}(\mathrm{ppm})$ & 592 & 191 & 399 & 1,410 & 49 \\
\hline Temp $\left({ }^{\circ} \mathrm{C}\right)$ & 21.6 & 3.6 & 12.7 & 27.1 & 50 \\
\hline RH (\%) & 48 & 15 & 14 & 87 & 50 \\
\hline
\end{tabular}

${ }^{1}$ Short-lived $\alpha$-activity.

${ }^{2}$ Long-lived $\alpha$-activity.

${ }^{3}$ Equilibrium factor; because this factor requires concurrent measurements of radon and SLA, the data size is lower than other variables.

Table 3. Radon and particle radioactivity in family rooms and basements.

\begin{tabular}{|c|c|c|c|c|c|c|c|c|c|c|}
\hline \multirow{2}{*}{ Species } & \multicolumn{5}{|c|}{ Family room } & \multicolumn{5}{|c|}{ Basement } \\
\hline & Mean & SD & Min & Max & $\mathrm{N}$ & Mean & SD & Min & Max & $\mathrm{N}$ \\
\hline Radon $\left(\mathrm{Bq} \mathrm{m}^{-3}\right)$ & 31.1 & 28.3 & 3.7 & 96.2 & 38 & 105.0 & 76.6 & 11.1 & 288.6 & 18 \\
\hline Positive ions (ions $\mathrm{cm}^{-3}$ ) & 1,064 & 636 & 490 & 2,231 & 10 & 2,876 & 1,896 & 928 & 6,240 & 8 \\
\hline Negative ions (ions $\mathrm{cm}^{-3}$ ) & 981 & 843 & 132 & 3,036 & 10 & 2,445 & 1,737 & 881 & 5,403 & 8 \\
\hline $\mathrm{SLA}^{1}\left(\mathrm{~Bq} \mathrm{~m}^{-3}\right)$ & 24.9 & 16.8 & 5.3 & 52.4 & 11 & 63.9 & 38.5 & 13.5 & 164.5 & 15 \\
\hline $\operatorname{LLA}^{2}\left(\mathrm{mBq} \mathrm{m}^{-3}\right)$ & 1.06 & 0.54 & 0.09 & 2.72 & 39 & 1.25 & 0.79 & 0.14 & 3.50 & 14 \\
\hline $\mathrm{F}$ factor $^{3}$ & 0.59 & 0.09 & 0.45 & 0.69 & 5 & 0.59 & 0.24 & 0.23 & 0.92 & 13 \\
\hline $\mathrm{PM}_{2.5}\left(\mu \mathrm{g} \mathrm{m}^{-3}\right)$ & 7.0 & 3.9 & 1.6 & 16.8 & 39 & 3.6 & 2.0 & 1.0 & 7.9 & 15 \\
\hline Sulfur $\left(\mu \mathrm{g} \mathrm{m}^{-3}\right)$ & 0.193 & 0.117 & 0.018 & 0.436 & 39 & 0.153 & 0.084 & 0.025 & 0.369 & 15 \\
\hline $\mathrm{CO}_{2}(\mathrm{ppm})$ & 596 & 160 & 432 & 1,135 & 36 & 580 & 265 & 399 & 1,410 & 13 \\
\hline $\operatorname{Temp}\left({ }^{\circ} \mathrm{C}\right)$ & 22.2 & 3.3 & 12.9 & 27.1 & 36 & 19.9 & 4.0 & 12.7 & 25.0 & 14 \\
\hline RH (\%) & 48 & 14 & 14 & 69 & 36 & 46 & 18 & 16 & 87 & 14 \\
\hline
\end{tabular}

${ }^{1}$ Short-lived $\alpha$-activity.

${ }^{2}$ Long-lived $\alpha$-activity.

${ }^{3}$ Equilibrium factor.

$\mathrm{p}<0.001)$ and negative $\left(\mathrm{R}^{2}=0.80, \mathrm{p}<0.001\right)$ ions, indicating that air ions are associated with radon progeny from radon decay. The unipolarity $\left(\mathrm{n}^{+} / \mathrm{n}^{-}\right)$of positive and negative ions was 1.4. The average air ions to radon quotients were $61 \times 10^{6}$ ions $\mathrm{Bq}^{-1}$ for $\mathrm{n}^{+} / \mathrm{Rn}$ and $51 \times 10^{6}$ ions $\mathrm{Bq}^{-1}$ for $\mathrm{n}^{-} / \mathrm{Rn}$, which are slightly higher than a previous finding $\left(40 \times 10^{6}\right.$ and 31 $\times 10^{6}$ ions $\mathrm{Bq}^{-1}$, respectively) (Kolarz et al., 2009). For the basement, the association $\left(\mathrm{R}^{2}\right)$ between positive and negative ions was $0.99(\mathrm{p}<0.001)$ and the associations with radon were 0.90 for positive ions and 0.87 for negative ions. The unipolarity was 1.2 , and the quotients of $\mathrm{Rn} / \mathrm{n}^{+}$and $\mathrm{Rn} / \mathrm{n}^{-}$ were $38 \times 10^{6}$ and $33 \times 10^{6}$ ions $\mathrm{Bq}^{-1}$ for positive and negative ions, respectively. For the family room, the unipolarity was 1.5 and the quotients were $79 \times 10^{6}$ and $65 \times 10^{6}$ ions $\mathrm{Bq}^{-1}$ for positive and negative ions, respectively. Positive ions were highly correlated with negative ions $\left(\mathrm{R}^{2}=0.81, \mathrm{p}<0.001\right)$, while air ions were poorly correlated with radon (positive ions: $\mathrm{R}^{2}=0.29, \mathrm{p}=0.112$; negative ions: $\mathrm{R}^{2}=0.09, \mathrm{p}=0.403$ ). The difference in associations indicates that air ions in family rooms may have originated not only from the basement radon but also from the outdoor air.
For SLA, an overall average across all home measurements was $47.4 \pm 36.5 \mathrm{~Bq} \mathrm{~m}^{-3}$. The SLA averaged $24.9 \pm 16.8 \mathrm{~Bq} \mathrm{~m}^{-3}$ in family rooms, while it averaged $63.9 \pm 38.5 \mathrm{~Bq} \mathrm{~m}^{-3}$ in basements, which is over two times higher than the family room measurements. For LLA, an overall average was 1.11 $\pm 0.61 \mathrm{mBq} \mathrm{m}^{-3}$. The average was $1.06 \pm 0.54 \mathrm{mBq} \mathrm{m}^{-3}$ in family rooms, while it was $1.25 \pm 0.79 \mathrm{mBq} \mathrm{m}^{-3}$ in basements. The SLA and LLA in the basement were higher than those in the family room. As expected, the radioactivity of shortlived progeny was substantially greater than that of longlived progeny because the decay of short-lived progeny is much faster to yield greater $\alpha$-activity. Note again that two measurements represent the radioactivity derived from a different particle size: SLA represents the radioactivity of non-size-selected particles (i.e., total suspended particles), whereas LLA represents the radioactivity of $\mathrm{PM}_{2.5}$. However, since radioactivity is predominantly associated with fine particles due to their larger surface area (Akbulut et al., 2012), the radioactive measurements from different particle sizes would not meaningfully contribute to the difference.

The exposure to indoor $\mathrm{PM}_{2.5}$ is important not only for 
toxicity due to trace metals but due to attached particle radioactivity (i.e., SLA and LLA) because it can be deeply inhaled. Indoor sulfur concentrations of $\mathrm{PM}_{2.5}$ were used to determine the infiltration of outdoor $\mathrm{PM}_{2.5}$. Outdoor $\mathrm{PM}_{2.5}$ can enter the home through windows, doors, cracks and other openings in the structure, and as make-up air in heating and air-conditioning systems. Overall $\mathrm{PM}_{2.5}$ and sulfur concentrations across all home measurements were $6.0 \pm 3.7$ and $0.189 \pm 0.109 \mu \mathrm{g} \mathrm{m}^{-3}$, respectively. The $\mathrm{PM}_{2.5}$ concentrations averaged $7.0 \pm 3.9 \mu \mathrm{g} \mathrm{m} \mathrm{m}^{-3}$ and sulfur concentrations averaged $0.193 \pm 0.117 \mu \mathrm{g} \mathrm{m}^{-3}$ in family rooms. In comparison, basement concentrations were lower with $\mathrm{PM}_{2.5}$ averaging $3.6 \pm 2.0 \mu \mathrm{g} \mathrm{m}^{-3}$ and sulfur averaging $0.153 \pm 0.084 \mu \mathrm{g} \mathrm{m}^{-3}$. This difference can be explained by the greater infiltration of outdoor $\mathrm{PM}_{2.5}$ and sulfur into the living area compared to the basement.

\section{Radon and Particle Radioactivity by Season}

Indoor measurements were also conducted for non- heating (June-September) and heating (October-March) seasons in the same homes. Fig. 1 shows the average and standard error of seasonal measurements. The summaries are also available in Table S1 (Appendix). Radon averaged $48.0 \pm 67.3 \mathrm{~Bq} \mathrm{~m}^{-3}$ for the non-heating season, while it averaged $62.8 \pm 49.6 \mathrm{~Bq} \mathrm{~m}^{-3}$ for the heating season. Positive and negative ions for non-heating season averaged 1,595 \pm 1,447 and 1,484 $\pm 1,420$ ions $\mathrm{cm}^{-3}$, respectively. As for the seasonal variation of radon, air ions were greater for the heating season, with averages of 2,213 $\pm 1,807$ positive ions $\mathrm{cm}^{-3}$ and 1,817 $\pm 1,621$ negative ions $\mathrm{cm}^{-3}$. The same variation in radon and air ions by seasons and places indicates their relevance, as found in previous studies (Kolarz et al., 2009). SLA and LLA for non-heating season averaged 57.3 \pm 53.0 $\mathrm{Bq} \mathrm{m}^{-3}$ and $1.22 \pm 0.57 \mathrm{mBq} \mathrm{m}^{-3}$, respectively, whereas they averaged $40.2 \pm 15.3 \mathrm{~Bq} \mathrm{~m}^{-3}$ and $1.01 \pm 0.64 \mathrm{mBq} \mathrm{m}^{-3}$, respectively, for the heating season. The $\mathrm{PM}_{2.5}$ and sulfur concentrations for non-heating season averaged 7.1 \pm 3.6 and $0.231 \pm 0.120 \mathrm{\mu g} \mathrm{m}^{-3}$, respectively, whereas they averaged
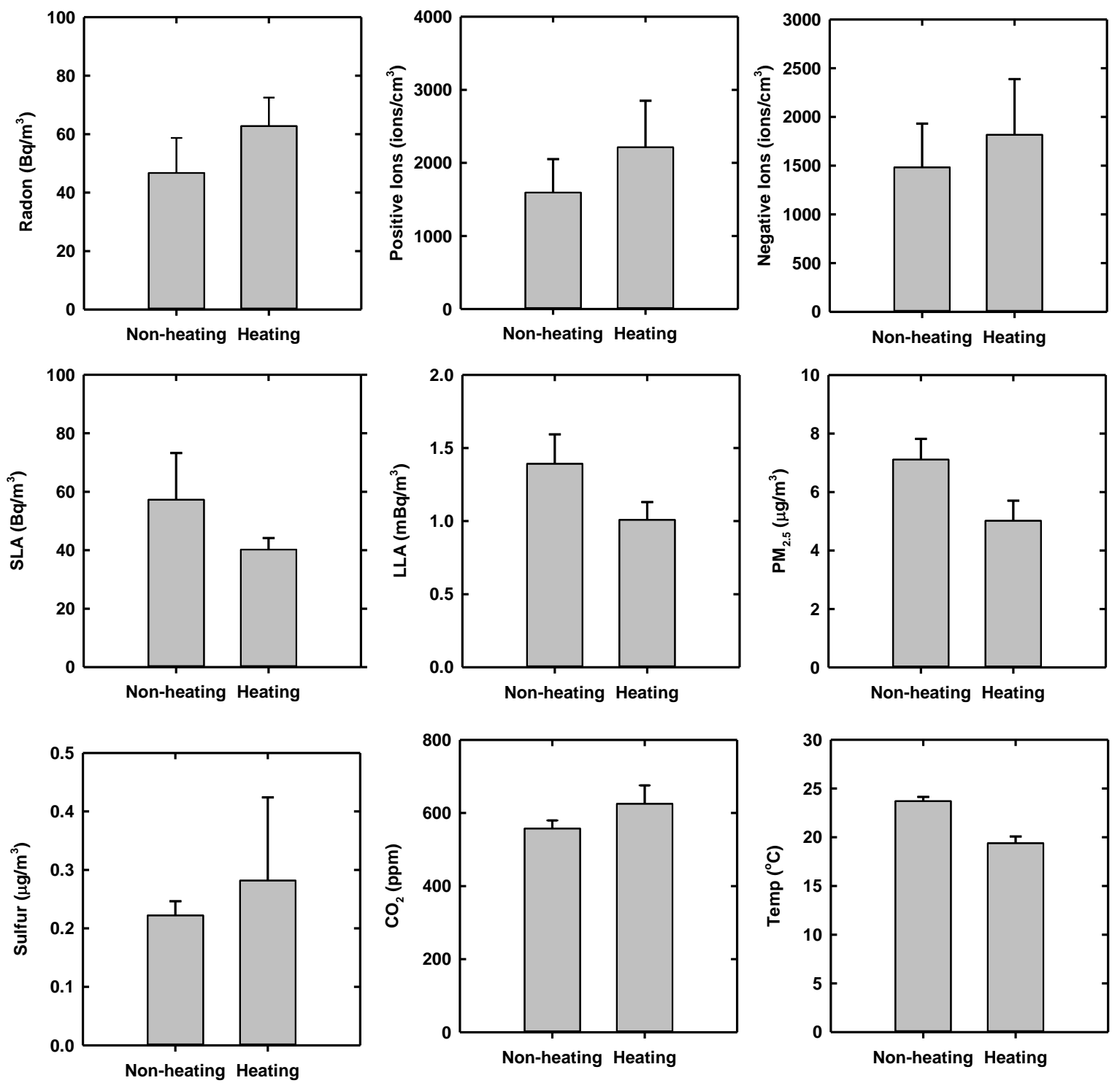

Fig. 1. Radon and particle radioactivity for non-heating and heating seasons. 
$5.0 \pm 3.6$ and $0.137 \pm 0.076 \mu \mathrm{g} \mathrm{m}^{-3}$, respectively, for the heating season. The $\mathrm{PM}_{2.5}$, sulfur, SLA, and LLA were much higher for the non-heating season than the heating season, which is the same variation of seasonal $\mathrm{PM}_{2.5}$ and sulfur concentrations measured at the Harvard Supersite located at downtown Boston (Kang et al., 2010).

\section{Regression Analysis Results}

Table 4 summarizes the univariate associations between the species associated with particle radioactivity, $\mathrm{PM}_{2.5}$, and sulfur concentrations. Linear mixed-effect regression indicated that SLA was significantly associated with radon $\left(\mathrm{R}^{2}=0.55, \mathrm{p}<0.001\right)$, and LLA was significantly associated with sulfur $\left(R^{2}=0.46, p<0.001\right)$. Fig. 2 also compares the associations of LLA with $\mathrm{PM}_{2.5}$ and sulfur. LLA was associated more with sulfur $\left(\mathrm{R}^{2}=0.46, \mathrm{p}<0.001\right)$ than $\mathrm{PM}_{2.5}\left(\mathrm{R}^{2}=0.09, \mathrm{p}=0.030\right)$ in all seasons. Sulfur is likely a better proxy of outdoor infiltration than $\mathrm{PM}_{2.5}$, with no seasonal variation. This may be because indoor $\mathrm{PM}_{2.5}$ could also be affected by indoor $\mathrm{PM}_{2.5}$ generated from cooking, gas stoves or kerosene heaters (Dockery and Pope, 1981; Derbez et al., 2018). In contrast, the radon was not significantly associated with all other variables except SLA. The SLA was not significantly associated with LLA, PM 2.5 , and sulfur, whereas the LLA was not significantly associated with radon, SLA, and $\mathrm{PM}_{2.5}$.

\section{DISCUSSION}

Radon progeny attached to existing particles (especially $\mathrm{PM}_{2.5}$ ) are of great concern as the radioactive particles can be inhaled and deposited in lung and subsequently translocate to other organs. This risk results in chronic exposure given the long lifetime of the progeny (e.g., ${ }^{210} \mathrm{~Pb}$ : half-life time $=$ 22.3 years) and if strategies to vent enclosed spaces regularly and/or to limit the ingress to such places are not adopted. In this study, we characterized indoor exposure to radon and particle radioactivity by measuring air ions, SLA and LLA. Furthermore, we estimated the indoor and outdoor origins of radon progeny that contribute to indoor particle radioactivity.

Overall radon levels were estimated to be $54.9 \mathrm{~Bq} \mathrm{~m}^{-3}$ ranging from 3.7 to $288.6 \mathrm{~Bq} \mathrm{~m}^{-3}$ in the study area: The radon levels in basements $\left(105.0 \mathrm{~Bq} \mathrm{~m}^{-3}\right)$ were over three times higher than in family rooms $\left(31.1 \mathrm{~Bq} \mathrm{~m}^{-3}\right)$. The Iowa

Table 4. Univariate regression results.

\begin{tabular}{|c|c|c|c|c|c|c|}
\hline \multirow{2}{*}{$\begin{array}{l}\text { Dependent } \\
\text { variables }\end{array}$} & \multicolumn{2}{|c|}{ Radon } & \multicolumn{2}{|c|}{ SLA } & \multicolumn{2}{|c|}{ LLA } \\
\hline & Coefficient & $p$-value & Coefficient & $p$-value & Coefficient & $p$-value \\
\hline Radon & - & - & 0.403 & $<0.001$ & 0.003 & 0.102 \\
\hline SLA $^{1}$ & 1.358 & $<0.001$ & - & - & 0.009 & 0.231 \\
\hline $\mathrm{LLA}^{2}$ & 18.22 & 0.102 & 9.209 & 0.231 & - & - \\
\hline $\mathrm{PM}_{2.5}$ & -4.513 & 0.031 & -1.865 & 0.298 & 0.048 & 0.030 \\
\hline Sulfur & -147.9 & 0.043 & -15.29 & 0.859 & 3.696 & $<0.001$ \\
\hline $\mathrm{F}$ factor & -159.5 & 0.039 & 25.12 & 0.580 & -0.984 & 0.367 \\
\hline
\end{tabular}

${ }^{1}$ Short-lived $\alpha$-activity.

${ }^{2}$ Long-lived $\alpha$-activity.

${ }^{3}$ Equilibrium factor.
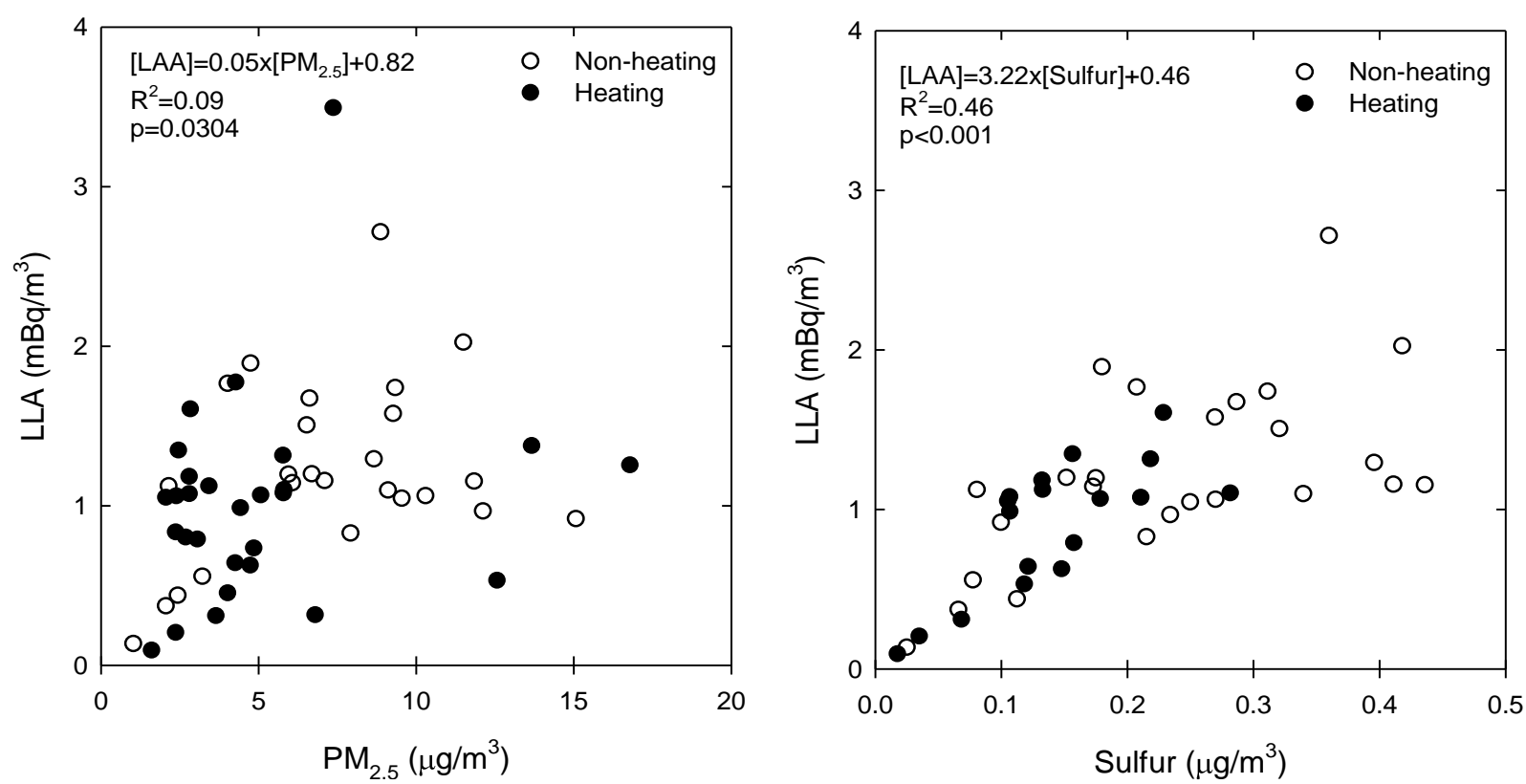

Fig. 2. Associations between long-lived $\alpha$-activity (LLA), $\mathrm{PM}_{2.5}$ and sulfur concentrations. 
radon lung cancer study including 1,027 home measurements observed that radon levels were lower at higher floors with averages of 170,89 and $70 \mathrm{~Bq} \mathrm{~m}^{-3}$ for the basement, first and second floors, respectively (Field et al., 2000). Thirteen European radon-cancer studies (Darby et al., 2005) found a mean radon level of $97 \mathrm{~Bq} \mathrm{~m}^{-3}$ in family rooms. Dudney et al. (1990) consistently found a higher level in basements than in living areas both during the summer $\left(26-420 \mathrm{~Bq} \mathrm{~m}^{-3}\right.$ in living areas vs. $53-530 \mathrm{~Bq} \mathrm{~m}^{-3}$ in basements) and the winter $\left(8-370 \mathrm{~Bq} \mathrm{~m}^{-3}\right.$ in living areas vs. $17-650 \mathrm{~Bq} \mathrm{~m}^{-3}$ in basements) in 70 homes of the southern U.S. Compared to these studies, our radon levels are slightly lower for several reasons such as inclusion of multi-floor apartments, better ventilation, different geology, and different construction materials (more wood, less mineral). Besides, based upon the EPA classification Iowa is in a higher-radon area (Zone 1, highest-radon-potential area) than Boston (Zone 2, moderate-radon-potential area). Air ions (positive and negative ions) were highly correlated with radon levels, suggesting that air ions are associated with radon decay. However, the association in family rooms only was weak possibly due to the intrusion of outdoor air ions. Contrary to a consistent diurnal variation in a multi-level unoccupied new building (Kolarz et al., 2009), we did not find the significant diurnal pattern in the levels of air ions. This may be because each home has radon sources (e.g., basement), which may be associated with a variety of potential ventilation mechanisms.

The equilibrium factor was calculated from a ratio of radon and SLA. Estimating the factor is important in risk assessment related to inhalation of radon. Our estimated factors in family rooms and basements were 0.59 and 0.59 , respectively. Swedjemark (1983) found that the F factors ranged from 0.28 to 0.80 and were influenced by multiple factors including house types, locations, and air exchange rates. Hopke et al. (1995) estimated an equilibrium factor of 0.41 from 7 home measurements of radon and its progeny in the northeastern U.S. and southeastern Canada. The U.S. EPA also assumed a factor of 0.5 to establish the action level of $148 \mathrm{~Bq} \mathrm{~m}^{-3}$ for home remediation (Bruno, 1983). Our findings on the equilibrium factors are reasonable and within the reported range by previous studies.

The LLA in basements was higher than that in family rooms, suggesting that the LLA might partly be affected by indoor SLA even though the non-significant association was found from the regression analysis. Similar to the LLA, the SLA was also higher in basements. Dudney et al. (1990) found that the short-lived radon progeny in family rooms were approximately half of the basement measurements in the southern U.S. cities. Fisenne et al. (Fisenne, 1993; Fisenne et al., 1996) determined the LLA on archived indoor air filters collected in a twelfth-floor apartment in southern New Jersey $\left(0.34 \mathrm{mBq} \mathrm{m}^{-3}\right.$ ranged from 0.08 to $\left.0.82 \mathrm{mBq} \mathrm{m}^{-3}\right)$ and in a fifth-floor office in New York City $\left(0.15 \mathrm{mBq} \mathrm{m}^{-3}\right.$ ranged from 0.07 to $0.40 \mathrm{mBq} \mathrm{m}^{-3}$ ). In addition, they reported outdoor LLA levels were up to four times higher than corresponding indoor ones. For our study, even though we did not measure outdoor radioactivity, the outdoor LLA levels might also be higher than indoor ones in Boston. The higher activity in the non-heating season is likely because more particle radioactivity can come from outdoors, especially during this open-window season. Furthermore, the levels of LLA in our study were higher than those observed in New Jersey and New York City, possibly due to the higher radon potential in the Boston metropolitan area. The $\mathrm{PM}_{2.5}$ and sulfur concentrations in family rooms were higher than those in basements, whereas the LLA was higher in basements. However, in common, they were significantly higher during the non-heating season than the heating season. This can also be explained by greater air ventilation in the living area than in the basement. The summer is a preferable season to open windows rather than the winter. As discussed above, we used sulfur as a proxy of outdoor $\mathrm{PM}_{2.5}$ infiltration. This could be confirmed by the higher sulfur concentrations in family rooms and for the non-heating season. Overall, the $\mathrm{PM}_{2.5}$ and sulfur concentrations in this study were similar to the previous results $\left(8.8\right.$ and $0.30 \mu \mathrm{g} \mathrm{m}^{-3}$ for $\mathrm{PM}_{2.5}$ and sulfur, respectively) in the metropolitan Boston region (Tang et al., 2018).

Radon levels in this study exhibited significant seasonal variation as previous studies did. The seasonal variability was likely associated with the changes in the air exchange rate (e.g., frequency and duration of opening doors or windows) and radon entry (i.e., outdoor-indoor temperature gradient and the resulting soil-indoor pressure difference) by seasons. Several studies have also demonstrated a significant seasonal variation in indoor radon levels with a higher level in the winter than in the summer (Neville and Hultquist, 2008; Miles et al., 2012; Giagias et al., 2015). A radon survey in Athens, Greece, demonstrated that in the summer, indoor radon ranged from 42 to $186 \mathrm{~Bq} \mathrm{~m}^{-3}$ with $36 \%$ of residences exceeding the WHO guideline level of $100 \mathrm{~Bq} \mathrm{~m}^{-3}$. In contrast, in the winter, the levels ranged from 79 to $245 \mathrm{~Bq} \mathrm{~m}^{-3}$ with $60 \%$ of residences exceeding the guideline (Giagias et al., 2015). Particle radioactivity, SLA and LLA exhibited a similar variation with a higher value for the nonheating season, whereas radon and air ion levels exhibited a similar variation with a higher value for the heating season. Similar to our findings, Dudney et al. (1990) found that in the southern U.S. cities, the short-lived radon progeny in living areas ranged $22-356 \mathrm{~Bq} \mathrm{~m}^{-3}$ in the summer and $13-$ $463 \mathrm{~Bq} \mathrm{~m}^{-3}$ in the winter. Airborne particle concentrations either indoors or outdoors are thought to play an important role in determining the fate of newly generated radon progeny. Newly generated progeny from radon decay can undergo one of three processes: They can attach to existing airborne particles, a wall or other surface, or undergo radioactive decay before either of the first events occurs (NRC, 1988; Dudney et al., 1990). In this study, we found an association between radon and SLA with an $\mathrm{R}^{2}$ of 0.55 ( $\mathrm{p}$ 0.001 ). In contrast, we also found a different seasonal variation in radon and SLA. This discrepancy may be explained by a greater equilibrium factor (along with a higher $\mathrm{PM}_{2.5}$ concentration) for the non-heating season, which may also indicate that $\mathrm{PM}_{2.5}$ levels can be a factor to determine the SLA levels from radon decay.

We did not find a significant association between radon and LLA. Considering the short residence time of indoor 

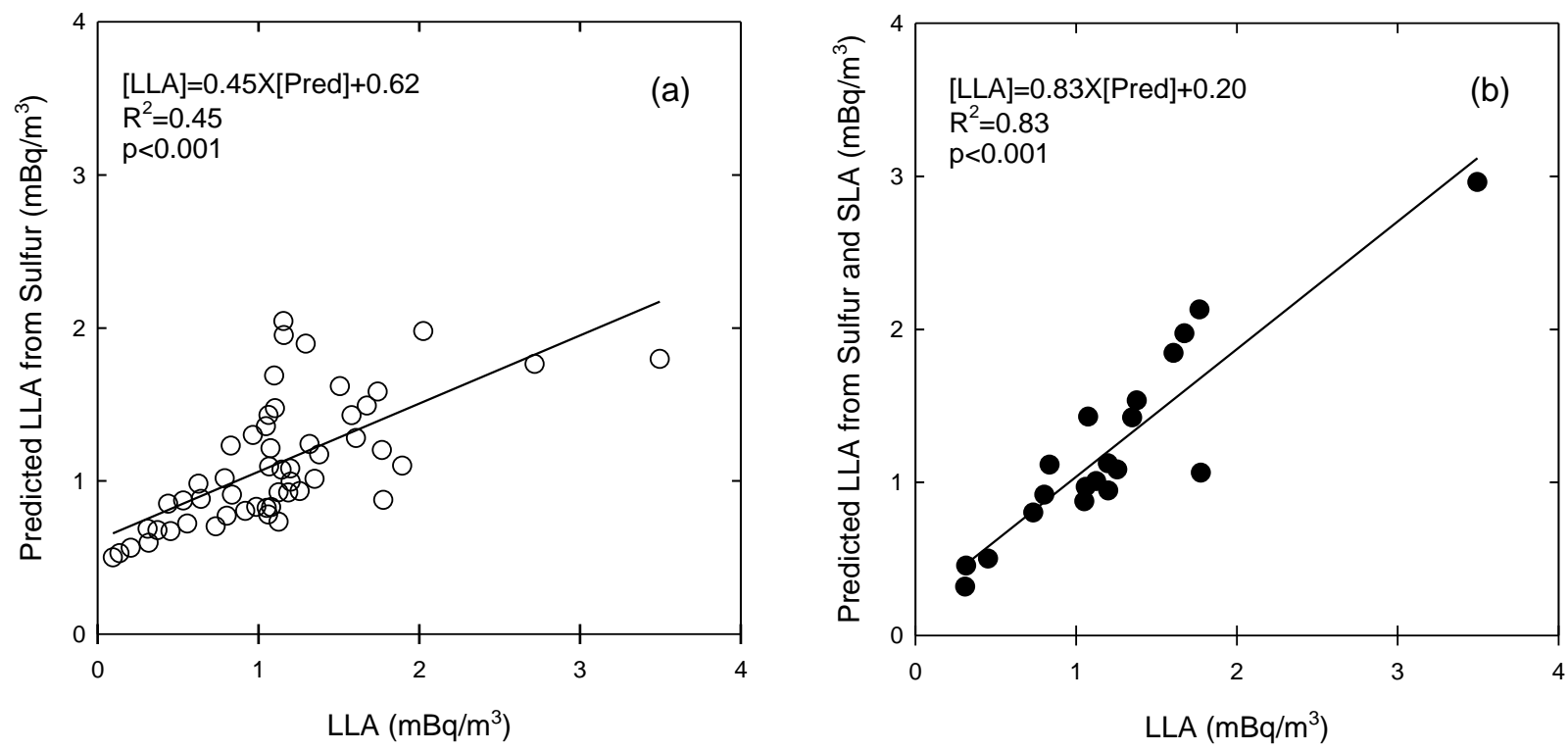

Fig. 3. Associations between the measured LLA and the predicted LLA from SLA and sulfur concentrations.

particles due to high infiltration in typical U.S. homes, indoor LLA may mainly be associated with the outdoor radioactivity. This is also supported by the higher outdoor levels than indoor levels in previous findings (Fisenne et al., 1996). However, the outdoor radioactivity might not be the only variable to account for the observed LLA. A higher LLA in basements was observed compared to family rooms. This may indicate some SLA can convert to LLA on the particles in stagnant air space such as the basement. To confirm this, a mixed regression model was used to obtain a coefficient and intercept between the observed LLA and either sulfur only (a proxy of outdoor radioactivity) or sulfur and SLA (a proxy of indoor radioactivity). The predicted values calculated from these model outputs were compared with observed LLA in Figs. 3(a) and 3(b). Compared to the regression model in Fig. 3(a) which was built with sulfur, the multivariate regression model built with sulfur and SLA was a better predictor of indoor LLA, with a higher slope and a lower intercept (Fig. 3(b)). This may indicate that indoor LLA was likely associated with mainly outdoor radioactivity, as well as partially indoor radon decay.

\section{CONCLUSIONS}

The levels of radon, particle radioactivity (SLA and LLA), and $\mathrm{PM}_{2.5}$ were concurrently measured in occupied homes. Indoor exposure to radon and $\alpha$ particles, which commonly occurs in residences, warrants great concern because of its potential health risks, which are increased by the presence of fine particles, as this fraction can be deeply inhaled. We found that the radon concentration and the particle radioactivity varied greatly among the homes and also differed by room (family room vs. basement) and season (heating vs. non-heating period). Additionally, we investigated sources of particle radioactivity and discovered that SLA was primarily associated with indoor radon decay, whereas LLA was likely connected to outdoor radioactivity.
Thus, our findings suggest that both the outdoor particle radioactivity and the indoor radon progeny concentration must be considered when assessing radiation exposure indoors; toward this objective, archived air filter analysis may be useful in estimating the radioactivity inside and outside homes. Finally, we note that our sample size limits our ability to evaluate correlations, thus decreasing the statistical power and generalizability of our results.

\section{ACKNOWLEDGMENTS}

This research was funded by the U.S. EPA grants (RD835872 and RD-834798) and the Coway Ltd. R\&D grant. Its contents are solely the responsibility of the grantee and do not necessarily represent the official views of the granters. Further, the granters do not endorse the purchase of any commercial products or services mentioned in the publication. This publication was supported by resources from the VA Boston Healthcare System. The views expressed in this article are those of the authors and do not necessarily reflect the position or policy of the Department of Veterans Affairs or the United States government.

\section{SUPPLEMENTARY MATERIAL}

Supplementary data associated with this article can be found in the online version at http://www.aaqr.org.

\section{EFERENCES}

Akbulut, S., Krupińska, B., Worobiec, A., Cevik, U., Taskın, H., Van Grieken, R., Samek, L. and Wiłkojć, E. (2012). Gross alpha and beta activities of airborne particulate samples from Wawel Royal Castle Museum in Cracow, Poland. J. Radioanal. Nucl. Chem. 295: 15671573. https://doi.org/10.1007/s10967-012-1983-8

Bruno, R.C. (1983). Sources of Indoor Radon in Houses: A 
Review. J. Air Pollut. Control Assoc. 33: 105-109. https://doi.org/10.1080/00022470.1983.10465550

Case, M.W., Williams, R., Yeatts, K., Chen, F.L., Scott, J., Svendsen, E. and Devlin, R.B. (2008). Evaluation of a direct personal coarse particulate matter monitor. Atmos. Environ. 42: 4446-4452. https://doi.org/10.1016/j.atmos env.2008.02.023

Darby, S., Hill, D., Auvinen, A., Barros-Dios, J.M., Baysson, H., Bochicchio, F., Deo, H., Falk, R., Forastiere, F., Hakama, M., Heid, I., Kreienbrock, L., Kreuzer, M., Lagarde, F., Makelainen, I., Muirhead, C., Oberaigner, W., Pershagen, G., Ruano-Ravina, A., Ruosteenoja, E., Rosario, A.S., Tirmarche, M., Tomasek, L., Whitley, E., Wichmann, H.E. and Doll, R. (2005). Radon in Homes and Risk of Lung Cancer: Collaborative Analysis of Individual Data From 13 European Case-Control Studies. BMJ 330: 223. https://doi.org/10.1136/bmj.38308.477650.63

Derbez, M., Wyart, G., Le Ponner, E., Ramalho, O., Riberon, J. and Mandin, C. (2018). Indoor air quality in energy-efficient dwellings: Levels and sources of pollutants. Indoor Air 28: 318-338. https://doi.org/10.11 11/ina.12431

Dockery, D.W. and Pope, C.A. (1981). Indoor-outdoor relationships of respirable sulfates and particles. Atmos. Environ. 15: 335-343. https://doi.org/10.1016/0004-698 1(81)90036-6

Dua, S.K., Biswas, S.K., Szerszen, P., Boudreaux, J. and Ebadian, M.A. (1999). Measurement of surface alpha contamination using electret ion chambers. Health Phys. 76: 664-674. https://doi.org/10.1097/00004032-199906 000-00010

Dudney, C.S., Hawthorne, A.R., Wallace, R.G. and Reed, R.P. (1990). Radon-222, 222Rn progeny, and 220Rn progeny levels in 70 houses. Health Phys. 58: 297-311. https://doi.org/10.1097/00004032-199003000-00008

Field, R.W., Steck, D.J., Smith, B.J., Brus, C.P., Fisher, E.L., Neuberger, J.S., Platz, C.E., Robinson, R.A., Woolson, R.F. and Lynch, C.F. (2000). Residential radon gas exposure and lung cancer: The Iowa Radon Lung Cancer Study. Am J Epidemiol. 151: 1091-1102. https://doi.org/10.1093/oxfordjournals.aje.a010153

Fisenne, I.M. (1993). Initial study of ${ }^{210} \mathrm{pb}$ in indoor air. Health Phys. 64: 423-425. https://doi.org/10.1097/0000 4032-199304000-00012

Fisenne, I.M., Keller, H.W. and Keller, E.W. (1996). ${ }^{210} \mathrm{pb}$ in indoor air by total alpha measurement. Health Phys. 71: 723-726. https://doi.org/10.1097/00004032-1996110 00-00013

Giagias, V., Burghele, D. and Cosma, C. (2015). Seasonal variation of indoor radon in dwellings from Athens, Greece. Rom. J. Phys. 60: 1581-1588.

Goheen, S.C., McCulloch, M., Thomas, B.L., Riley, R.G., Sklarew, D.S., Mong, G.M., and Fadeff, S.K. (1994). DOE methods for evaluating environmental and waste management samples. Pacific Northwest Lab., Richland, WA (United States). https://doi.org/10.2172/10106316

Hopke, P.K., Jensen, B., Li, C.S., Montassier, N., Wasiolek, P., Cavallo, A.J., Gatsby, K., Socolow, R.H. and James, A.C. (1995). Assessment of the exposure to and dose from radon decay products in normally occupied homes. Environ. Sci. Technol. 29: 1359-1364. https://doi.org/10. 1021/es00005a031

Kang, C.M., Koutrakis, P. and Suh, H.H. (2010). Hourly measurements of fine particulate sulfate and carbon aerosols at the Harvard-U.S. Environmental Protection Agency Supersite in Boston. J. Air Waste Manage. Assoc. 60: 1327-1334. https://doi.org/10.3155/1047-3289.60.11. 1327

Kang, C.M., Achilleos, S., Lawrence, J., Wolfson, J.M. and Koutrakis, P. (2014). Interlab comparison of elemental analysis for low ambient urban $\mathrm{PM}_{2.5}$ levels. Environ. Sci. Technol. 48: 12150-12156. https://doi.org/10.1021/es50 $2989 \mathrm{j}$

Kolarz, P.M., Filipovic, D.M. and Marinkovic, B.P. (2009). Daily variations of indoor air-ion radon concentrations. Appl. Radiat. Isot. 67: 2062-2067. https://doi.org/10.101 6/j.apradiso.2009.07.023

Kotrappa, P. and Stieff, R.L. (2003). An advanced E-perm system for simultaneous measurement of concentrations of radon gas, radon progeny, equilibrium ratio and unattached radon progeny. Preceedings of the 2003 International Radon Symposium, Nashville TN, 2003.

Kotrappa, P., Dua, S.K., Gupta, P.C. and Mayya, Y.S. (1981). Electret--A new tool for measuring concentrations of radon and thoron in air. Health Phys. 41: 35-46. https://doi.org/10.1097/00004032-198107000-00004

Lee, S.J., Demokritou, P., Koutrakis, P. and DelgadoSaborit, J.M. (2006). Development and evaluation of personal respirable particulate sampler (PRPS). Atmos. Environ. 40: 212-224. https://doi.org/10.1016/j.atmosenv. 2005.08.041

Miles, J.C., Howarth, C.B. and Hunter, N. (2012). Seasonal variation of radon concentrations in UK homes. J. Radiol. Prot. 32: 275-287. https://doi.org/10.1088/0952-4746/3 2/3/275

National Research Council (NRC) (1988). Health risks of radon and other internally deposited alpha-emitters: BEIR IV. The National Academies Press, Washington, DC, https://doi.org/10.17226/1026

Neville, J.D. and Hultquist, D.J. (2008). Seasonal radon variations in Utah testing results: Shortterm test results within $10 \%$ of the EPA threshold (4.0 PCI/L) should be repeated in a different season. Proceedings of the American Association of Radon Scientists and technologists, Las Vegas NV, 2008.

Offermann, F.J., Sextro, R.G., Fisk, W.J., Nazaroff, W.W., Nero, A.V., Revzan, K.L. and Yater, J. (1984). Control of respirable particles and radon progeny with portable air cleaners. Lawrence Berkerly Laboratory, USA. https://doi.org/10.2172/6785011

Porstendorfer, J. (1994). Properties and behaviour of radon and thoron and their decay products in the air. J. Aerosol Sci. 25: 219-263. https://doi.org/10.1016/0021-8502(94) 90077-9

Sarnat, J.A., Long, C.M., Koutrakis, P., Coull, B.A., Schwartz, J. and Suh, H.H. (2002). Using sulfur as a tracer of outdoor fine particulate matter. Environ. Sci. Technol. 36: 5305-5314. https://doi.org/10.1021/es025796b 
Sheets, R.W. and Thompson, C.C. (1994). Determination of atmospheric lead-210 by alpha-scintillation counting of air filters. J. Radioanal. Nucl. Chem. 180: 171-177. https://doi.org/10.1007/BF02039916

Swedjemark, G.A. (1983). The equilibrium factor F. Health Phys. 45: 453-462. https://doi.org/10.1097/00004032-19 8308000-00021

Tang, C.H., Garshick, E., Grady, S., Coull, B., Schwartz, J. and Koutrakis, P. (2018). Development of a modeling approach to estimate indoor-to-outdoor sulfur ratios and predict indoor $\mathrm{PM}_{2.5}$ and black carbon concentrations for Eastern Massachusetts households. J. Exposure Sci. Environ. Epidemiol. 28: 125-130. https://doi.org/10.1038 /jes.2017.11

U.S. EPA (1997). Exposure factors handbook Volume I: General factors. U.S. Environment Protection Agency. Washington DC.

U.S. EPA (2003). EPA assessment of risks from radon in homes. U.S. Environment Protection Agency. Washington
DC.

United Nations Scientific Committee on the Effects of Atomic Radiation (UNSCEAR) (2000). Sources and Effects of Ionizing Radiation. UNSCEAR 2000 Report to the General Assembly with Scientific Annesxes. Vol I: Sources. United Nations, New York.

World Health Organization (WHO) (2007). Indoor air pollution: National burden of disease estimates. WHO Press, World Health Organization, Geneva.

World Health Organization (WHO) (2009). WHO handbook on indoor radon: A public health perspective. Zeeb, $\mathrm{H}$. and Shannoun, F. (Eds.). WHO Press, World Health Organization, Geneva.

Received for review, January 28, 2020

Revised, January 28, 2020

Accepted, April 8, 2020 